\title{
Assessment of Waste Management Strategies among Staff and Students in Rivers State College of Health Science and Technology, Port Harcourt, Nigeria.
}

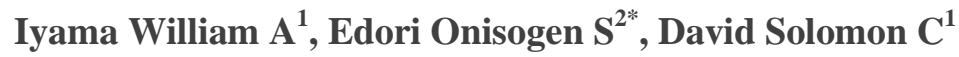 \\ ${ }^{1}$ Rivers State College of Health Science and Technology, Port Harcourt, Nigeria \\ ${ }^{2}$ Department of Chemistry, Ignatius Ajuru University of Education, Rumuolumeni, P.M.B. 5047, Port Harcourt \\ Rivers State, Nigeria
}

*Corresponding Author: Edori Onisogen S., Department of Chemistry, Ignatius Ajuru University of Education, Rumuolumeni, P.M.B. 5047, Port Harcourt Rivers State, Nigeria.

\begin{abstract}
The research work focuses on waste management strategies among staff and students in Rivers State College of Science and Technology, Rumueme, Port Harcourt.Precisely, one hundred and seventyone (171) was used as the sample size. These were either students or staff of the above named college. The major instrument that was used for data collection for thepresent study was self-structured survey or questionnaire, which was form by the investigator to suit the reason or purpose of the study. The data collected and analyzed revealed that that proper sanitary container and adequate dumpsite, health policies and enforcement will enhance healthy waste management strategies in the college. Secondly, the poor sanitary environment can enhance outbreak of disease in the school corroborated by incessant infection records. $67.1 \%$ agreed that poor waste management affects academic performance and also inadequate manpower (76.1\%) and poor health education affect waste management practices in our institutions.
\end{abstract}

Keywords: Waste, Waste management, Staff, Students, College, waste bins

\section{INTRODUCTION}

In the history of man waste management to the environment has been a great challenge as long as human exist, there has been the possibility of insanitary environment which has caused great health challenge to human healthy living. According to a jointly published data by WHO and UNICEF in the month of September, (2014), 36 out of a hundred of the world's populace do not have access to simple sanitation services and 768 million individuals frequently are deprived of clean drinking water and are disposed to dirty environment. Inaccessibility to proper sanitary environment and hygienic water cause death of up to 4,000 vulnerable children daily. This contributed to the cycle of poverty for families and communities in Nigeria, without water, sanitation and hygiene, efficient and sustainable development is unattainable. Manson, (2015) lack of adequate management of waste will result to health challenges to human through which water source will be contaminated ether by improper disposal of waste or hazardous discharge of substances, in one's environment leading to outbreak of disease like cholera, typhoid, dysentery and others which is associated poor management of these hazardous substances.

The management of waste and its disposal and related actions essentially must be based on the source, foundation and nature of waste generated. This comprises a mid others, the gathering, conveyance, handling and dumping of waste, which must go together with monitoring and guidelines (Jackson, 2016).

Furthermore, it also embraces the legal and monitoring structure or framework that relays to waste management surrounding regulation on recovering or reprocessing. The term normally relates to all kinds of waste, whether they are generated in the process of extracting the raw materials, the handling of raw materials into intermediary and ultimate products, or other human activities, that may be municipal (residential, institutional, commercial), agricultural and social (healthcare, household hazardous waste, sewage, sludge). Waste management is proposed to lessen hostile effects of waste on human health, the surroundings or aesthetics (Claire, 2015). 
Throughout greatest part of human history, the quantity of waste produced by humans was unimportant due to low population density and low societal levels of the manipulation of natural resources. Public waste generated throughout the ancient times and prior to the industrial revolution was primarily ashes and anthropological decomposable waste, and these were released back to the soil, the ultimate sink, with a minimum impact on the environment. Implements made out of timber or metal were generally recycled or handed down through the generations. Conversely, some civilizations do seem to have been more wasteful in their nature of waste generation than others. One of such groups particularly are the Maya tribe of Central America, that have fixed monthly ceremony, where the village settlers are gathered together and their garbage burnt in large dumps (Albert, 2011).

Waste management has always been a challenge to institutions, especially on effective management of those waste generated on daily basis in school premises. Waste disposal in school environment has always been a thing of concern to both staff and students as poor waste management has brought some health challenges which has enhanced the spread of communicable disease in the students environment. Contemporarily, it is crystal clear that there exists a great impact of poor management of waste, which affected all institution in Nigeria. Health is always paramount to everyone in which adequate cleanliness, storage and disposal of waste by students and staff will prevents most health diseases related to waste and will enhance a goal learning environment. Institutional Management and students' parts in the management of litters or wastes cannot be underrated, because they produce large quantities of waste and therefore, should be able to dispose such at the suitable and chosen sites to avert the spread of contagious diseases in the academic surroundings. Recently in the college due to poor facilities and equipment in management of these wastes, it has led to outbreak of malaria among students due to insanitary disposal of waste at the female hostels. Again, it has also led to odour nuisance, insanitary environment and also constant present of vermin's and reptiles in the surroundings.

The aim of this work is to assess waste management approaches among staff and students of Rivers State College of Health Science and Technology, Port Harcourt. This is achieved by assessment of the waste controlling policies and activities among staff and students in the College and determining the associated danger arising from improper waste management amongst staff and students of the College.

Research Questions

- What are the various ways in which waste can be managed among staff and students in the college?

- What are those various factors that contribute to poor waste management in the college?

- What are those effects of improper waste disposal to staff and students in the college?

\section{MATERIALS AND METHODS}

The research design that was employed for the study was a descriptive, non-experimental research. Michael and Richardson, (2014) stated that the method is used to describe systematically a situation through the analysis of variables.

Rivers State College of Health Science and Technology (RSCHST) is a public high Institution in Port Harcourt, Rivers State, Nigeria. It was established under the College of Health Science and Technology Law, 2001 and consists of school of Health Technology, School of Public Health Nursing and others. It is located in Mile 4, Orowo -Rumueme Community and shares boundary with Amaechi Drive and Agip flyover. It is a state government owned school which is managed by the Rivers State Government and headed by a provost.

The population of the study consists of one hundred and sixty staff and students in the College (160). The sample size is one hundred and ten (110) staff and students which is $(68.75 \%)$ of the total population used for the study. The research employed a simple random sampling technique devoid of bias.

The instrument that was used to collect data for this study was a self-structured questionnaire that was formulated by the researcher to suit the purpose of the study. The questionnaire was structured into two sections respectively. Section A was designed to elicit personal data from the respondents while 
section B contained questions posed in relations to the study objectives. The instrument were giving to the researcher supervisor to access the content in which various corrections were made and were rewritten by the researcher, which made the instrument valid for the research purpose. The method that was used to analyze the collected data was a descriptive statistics of frequency distribution tables and Percentages.

\section{Result PResentation}

Presentation of the data will be done using simple percentage and frequency distribution tables.

Table1. Distribution of Questionnaire

\begin{tabular}{|l|l|l|}
\hline 1 & Numbers of questionnaires distributed & 110 \\
\hline 2 & Numbers of questionnaires retrieved & 105 \\
\hline 3 & Numbers of questionnaires not retrieved & 5 \\
\hline 4 & Total Numbers of questionnaires used for analysis & 105 \\
\hline
\end{tabular}

Source: field survey 2018

Table 1 shows the distribution of questionnaire to the respondents at the study area. However, out of one hundred and ten (110) questionnaires that were distributed, only one hundred and five (105) was retrieved, five (5) were not retrieved. Based on this, a total of one hundred and five (105) questionnaires were used for the analysis.

Table2. Ways of Managing Waste in the College

\begin{tabular}{|c|c|c|c|c|c|c|c|}
\hline S/N & OPTIONS & Yes & $\%$ & No & $\%$ & Total & Total (\%) \\
\hline 1 & Employment of sanitary personnel. & 90 & 86 & 15 & 14 & 105 & 100 \\
\hline 2 & $\begin{array}{c}\text { Health education of staff and students on } \\
\text { waste disposal. }\end{array}$ & 69 & 66 & 36 & 34 & 105 & 100 \\
\hline 3 & Provision of more sanitary waste bins. & 80 & 78 & 25 & 22 & 105 & 100 \\
\hline 4 & Creation of waste dump site in the College & 70 & 67 & 35 & 33 & 105 & 100 \\
\hline
\end{tabular}

Source: Author field survey 2018
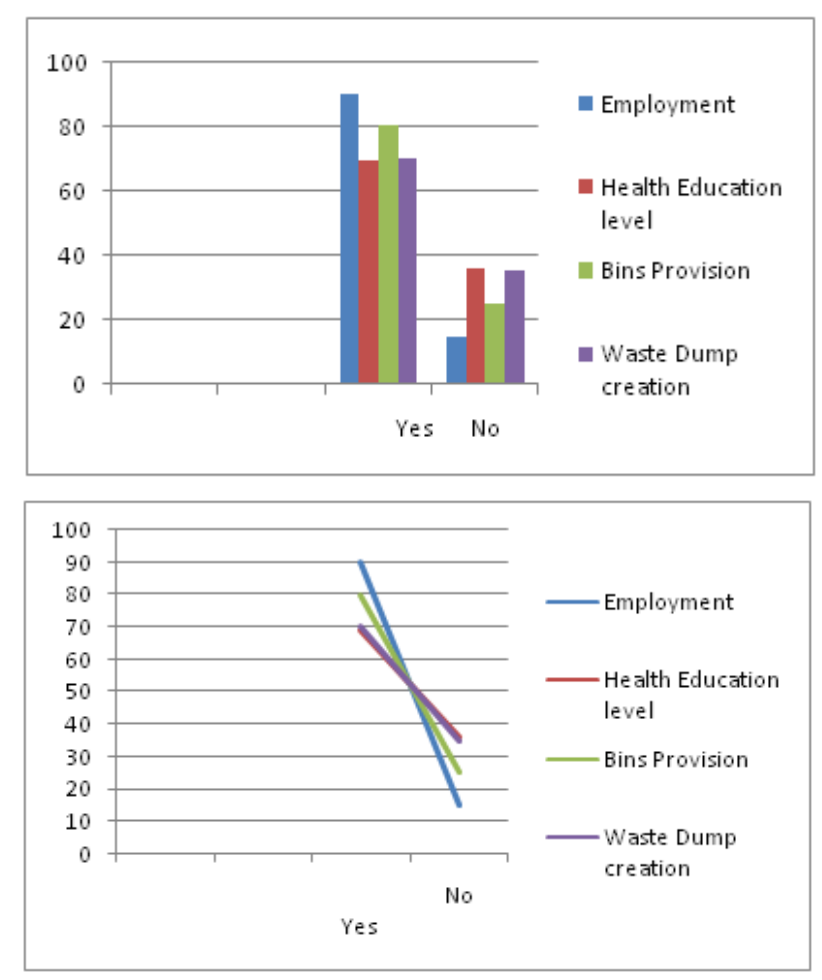

Table 2 shows that $90(86 \%)$ of the respondents said yes that employment of sanitary officer will enhance waste management, while 15(14\%) said No. 69 (66\%) of the staff and students agreed that periodic health education will enhance waste management in the college, while 36(34\%) disagreed. Also that $80(78 \%)$ of the respondents said yes that provision of sanitary container will enhance storage of waste in the college, while $25(22 \%)$ disagreed. Finally from the Table, $70(67 \%)$ of 
Assessment of Waste Management Strategies among Staff and Students in Rivers State College of Health Science and Technology, Port Harcourt, Nigeria

respondent agreed that waste dumpsite is necessary for waste disposal in the college, while $35(33 \%)$ disagreed.

Table3. Contributory Factors to Poor Waste Management in the College

\begin{tabular}{|c|c|c|c|c|c|c|c|}
\hline S/N & OPTIONS & Yes & \% & No & \% & Total & Total (\%) \\
\hline 1 & $\begin{array}{c}\text { Poor management policy on waste } \\
\text { management. }\end{array}$ & 70 & 67 & 35 & 33 & 105 & 100 \\
\hline 2 & Bad sanitary containers & 69 & 66 & 36 & 34 & 105 & 100 \\
\hline 3 & $\begin{array}{c}\text { Lack of manpower on waste } \\
\text { management. }\end{array}$ & 80 & 76.1 & 25 & 23.9 & 105 & 100 \\
\hline 4 & Poor health education. & 90 & 85.7 & 15 & 14.3 & 105 & 100 \\
\hline
\end{tabular}

Source: Author field survey 2018

Table 3 reveals that $70(67 \%)$ of the respondents said yes that poor management policy on waste management contributes to poor waste management in the college, while $35(33 \%)$ said No, 69 (66\%) opined that Bad sanitary containers contributes to poor waste management waste in the college, while $36(34 \%)$ disagreed. Also that 80(76.1) of the respondents said yes that lack of manpower on waste management contributes to poor waste management in the college, while $25(23.9 \%)$ disagreed. Finally from $90(85.7 \%)$ of respondent noted that Poor health education contributes to poor waste management in the college, while 35(22\%) disagreed.
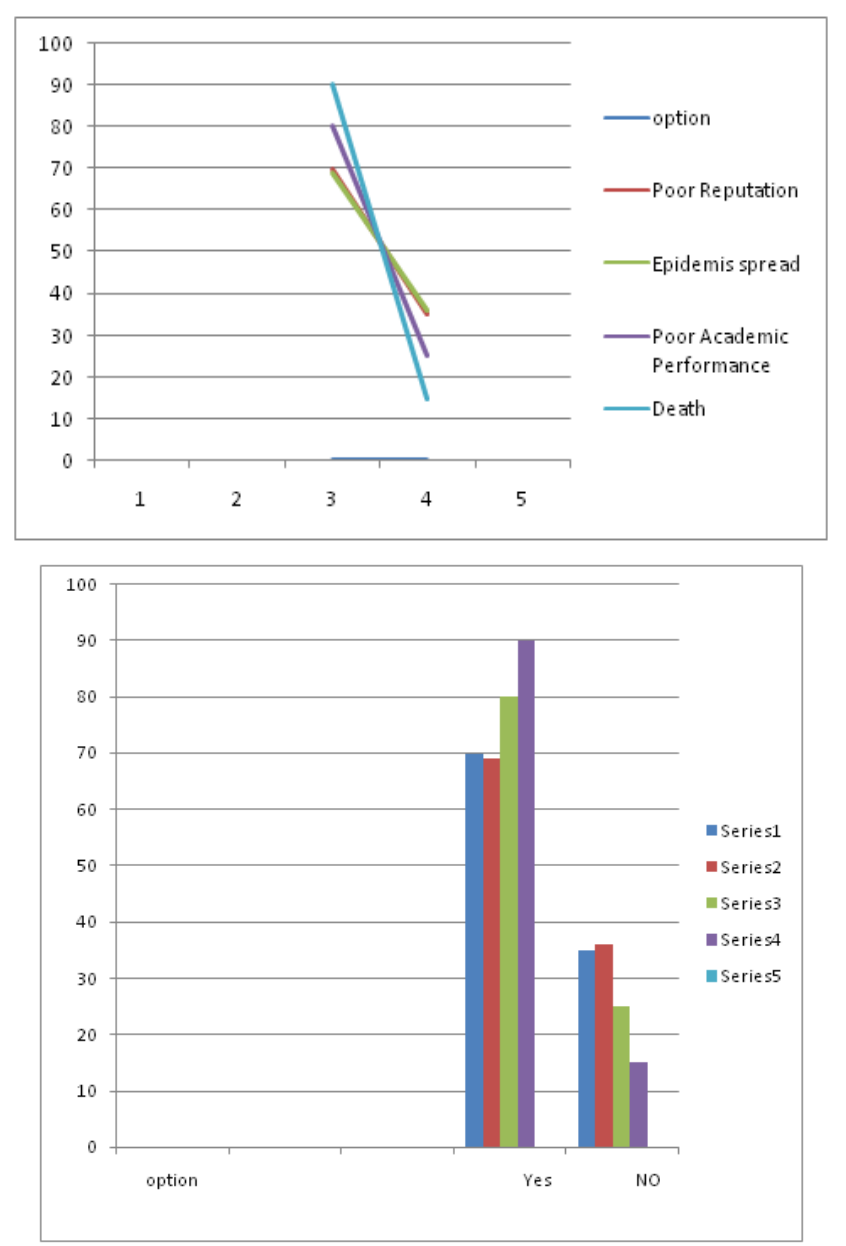

Table4. Effects of Poor Waste Management of Among Staff and Students in the College

\begin{tabular}{|c|c|c|c|c|c|c|c|}
\hline S/N & OPTIONS & Yes & $\%$ & No & $\%$ & Total & Total (\%) \\
\hline 1 & Bad reputation to the College. & 70 & 67 & 35 & 33 & 105 & 100 \\
\hline 2 & Epidemics situation. & 69 & 66 & 36 & 34 & 105 & 100 \\
\hline 3 & Poor academic performance. & 80 & 76.1 & 25 & 23.9 & 105 & 100 \\
\hline 4 & Death & 90 & 85.7 & 15 & 14.3 & 105 & 100 \\
\hline
\end{tabular}

Source: Author field survey 2018 
Table 4showedthat $70(67 \%)$ of the respondents noted that poor management of waste leads to bad reputation to the College, while $35(33 \%)$ said no. $69(66 \%)$ opined that poor management of waste leads to Epidemics situation, while 36(34\%) disagreed. 80(76.1) of the respondents assert that poor management of waste leads to Poor academic performance, while 25(23.9\%) disagreed. Finally from $90(85.7 \%)$ of respondent noted that poor management of waste lead to Death, while $15(14.3 \%)$ disagreed.
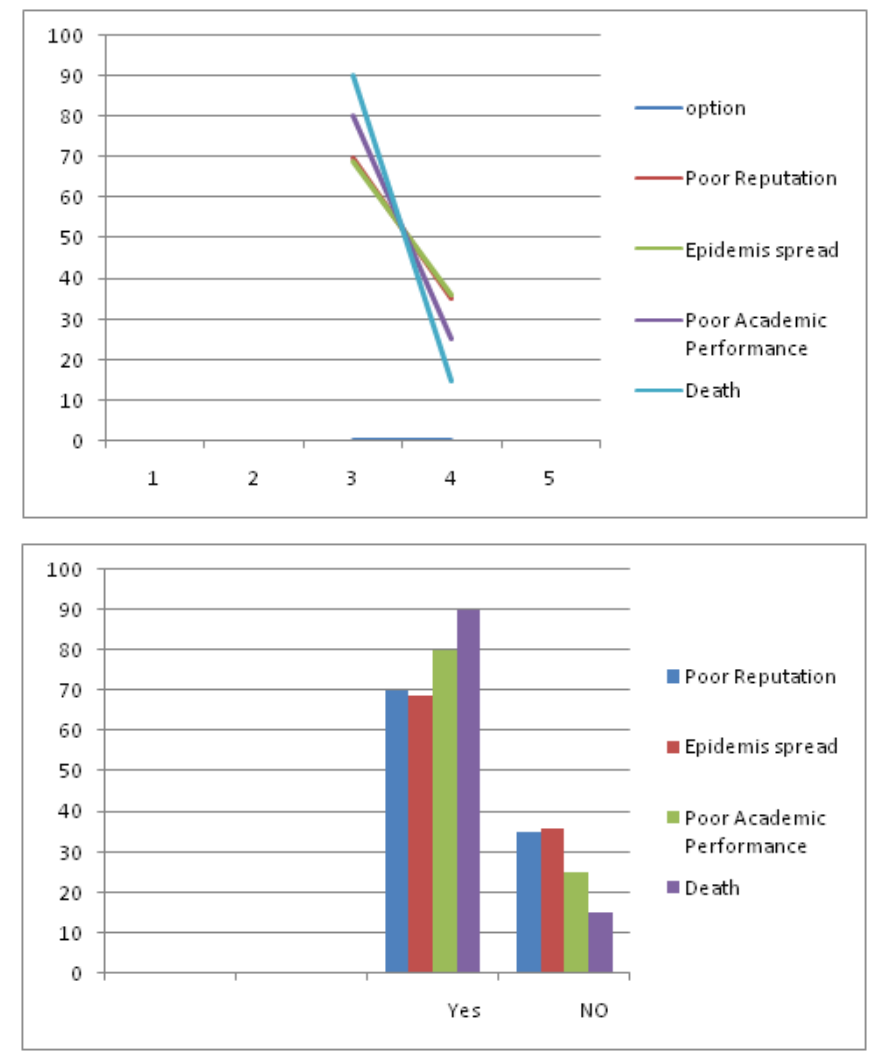

\section{DISCUSSION OF FINDING}

Table 1 shows that $90(86 \%)$ of the respondents said yes that employment of sanitary officer will enhance waste management, while 15(14\%) said No. 69 (66\%) of the staff and students agreed that periodic health education will enhance waste management in the college, while 36(34\%) disagreed. Also that $80(78 \%)$ of the respondents said yes that provision of sanitary container will enhance storage of waste in the college, while $25(22 \%)$ disagreed. Finally from the Table $70(67 \%)$ of respondent agreed that waste dump site is necessary for waste disposal in the college, while $35(33 \%)$ disagreed.

This finding above is however in line with Osere, (2014) who reported that employment of sanitary officer will enhance good waste management; also that periodic health education will enhance waste administration in the College.

Table 2 revealed that $70(67 \%)$ of the respondents said yes that poor management policy on waste management contributes to poor waste management in the college, while $35(33 \%)$ said No. $69(66 \%)$ opined that Bad sanitary containers contributes to poor waste management in the college, while $36(34 \%)$ disagreed. Also that $80(76.1)$ of the respondents said yes that lack of manpower on waste management contributes to poor waste management in the college, while 25(23.9\%) disagreed. Finally from $90(85.7 \%)$ of respondent noted that Poor health education contributes to poor waste management in the college, while 35(22\%) disagreed.

This is in correlation with Wilson,(2014) who noted poor management policy on waste management contributes to poor waste management in the College, also that sanitary containers contributes to poor waste management in the College.

Table 3 unveil that $70(67 \%)$ of the respondents noted that poor management of waste leads to bad reputation to the College, while $35(33 \%)$ said no. 69 (66\%) opined that poor management of waste 
leads to Epidemics situation, while 36(34\%) disagreed. 80 (76.1) of the respondents assert that poor management of waste leads to Poor academic performance, while 25(23.9\%) disagreed. Finally from $90(85.7 \%)$ of respondent noted that poor management of waste leads Death, while 15(14.3\%) disagreed.

This is in agreement with Michael, (2017) who reported that poor management of waste leads to bad reputation to the College, also that poor management of waste leads to epidemics situation.

\section{CONCLUSION}

Based on the findings of the research, the following conclusions were drawn. The research revealed that proper sanitary container and adequate dump site will enhance waste management in the college. Secondly, the study also revealed that poor sanitary environment can enhance outbreak of disease in the school. Finally, it was revealed that poor management policy can have positive and negative effect on waste management and disposal in the college. Based on various findings in this research work, it is recommended that various higher institution must ensure that they employ a sanitary officer to enhance adequate management and distribution of waste proper training and retraining of staff and students on disposal of waste should be done periodically, ministry of health and environment shouldalways ensure periodic inspection of high institutions to ensure certain standards are met with regardsto waste management and disposal and also institution's management must ensure there is an adequate policy statement and enforcement on disposal of waste to every individual in the college.

\section{REFERENCES}

[1] Albert, T. (2011). Waste management practices, university office of sustainability - Retrieved 3 March, 2014.

[2] Clarie, C. (2015).Poor waste management can encourage spread of communicable disease. Port Harcourt, Rivers State: Frank Publisher.

[3] David F. (2017) .Appropriate planning and receptacle provision and disposal of waste in school. Lagos :D-great Publisher.

[4] Frank, N. (2015). Health care technology advancement and effects of waste world-wide. Journal of advanced waste management 5(94): 47-45.

[5] Jackson, F. (2016). Waste management and disposal method, Abuja: Chidi Publisher.

[6] Manson, A (2015). Waste in a learning environment. Port Harcourt, Rivers State: Frank Publisher.

[7] Michael, D (2017) .Appropriate waste dump site must be sited in every learning environment to ensure adequate disposal of waste in the environment. New York, NY: woder Publisher.

[8] Osere, R. (2014).Waste found in college environment are generated more by staff and students. Port Harcourt, Rivers State: Frank Publisher.

[9] Richardson, A. (2014). Presence of sanitary container in the college to prevent littering of waste in the surroundings. Lagos: Wilson Publisher.

[10] Stephen, A. (2016) The proper care and sue of garbage disposal. May Retrieve 2017-03-03.

[11] WH.O and UNICEF(2014). United Nation Children and Education Fund, (2014). Environment statistics, unstates un.org. Retrieved 3 March, 2017.

[12] Wilson, S. (2014). “The History of waste” environmental chemistry.com. Retrieved 2016-12-2016.

Citation: Edori Onisogen S, “Assessment of Waste Management Strategies among Staff and Students in Rivers State College of Health Science and Technology, Port Harcourt, Nigeria.", International Journal of Advanced Research in Chemical Science, vol. 7, no.1 , p. 16-21, 2020. DOI: http://dx.doi.org/10.20431/23490403.0701003

Copyright: () 2020 Authors. This is an open-access article distributed under the terms of the Creative Commons Attribution License, which permits unrestricted use, distribution, and reproduction in any medium, provided the original author and source are credited. 